\title{
Augmentation of M-Type (KCNQ) Potassium Channels as a Novel Strategy to Reduce Stroke-Induced Brain Injury
}

\author{
Sonya M. Bierbower, ${ }^{1}$ Frank S. Choveau, ${ }^{1}$ James D. Lechleiter, ${ }^{2}$ and Mark S. Shapiro ${ }^{1}$ \\ Departments of ${ }^{1}$ Physiology and ${ }^{2}$ Cellular and Structural Biology, University of Texas Health Science Center, San Antonio, Texas 78229
}

Cerebral ischemic stroke is a worldwide cause of mortality/morbidity and thus an important focus of research to decrease the severity of brain injury. Therapeutic options for acute stroke are still limited. In neurons throughout the brain, "M-type" $\mathrm{K}^{+}$currents, underlain by KCNQ subunits 2-5, play dominant roles in control over excitability, and are thus implicated in myriad neurological and psychiatric disorders. Although KCNQ channel openers, such as retigabine, have emerged as anti-epilepsy drugs, their effects on ischemic injury remain unknown. Here, we investigated the protective effects of M-channel openers on stroke-induced brain injury in mouse photothrombotic and middle cerebral artery occlusion (MCAo) models. Both photothrombosis and MCAo led to rapid, predictable, and consistently sized necrotic brain lesions, inflammatory responses, and behavioral deficits. Administration of three distinct M-channel openers at $0-6 \mathrm{~h}$ after ischemic injury significantly decreased brain infarct size and inflammation, and prevented neurological dysfunction, although they were more effective when administered $0-3 \mathrm{~h}$ poststroke. Thus, we show beneficial effects against stroke-induced brain injury and neuronal death through pharmacological regulation of ion channels that control neuronal excitability.

Key words: ischemia; motor deficits; pathological disease; potassium channel; stroke

\section{Introduction}

Cerebrovascular stroke is a leading cause of adult disability (Sidney et al., 2013), with few current options to improve neurological outcomes. Recent advances suggest that stroke is a potentially treatable disease, leading to interest in developing novel neuroprotective therapeutics. KCNQ2 $-5 \mathrm{~K}^{+}$channels underlie neuronal M-currents, which are found ubiquitously in the nervous system. M-channels are important regulators of neuronal excitability since they stabilize the resting membrane potential, influence neuronal subthreshold excitability, and regulate spike generation (for a review, see Delmas and Brown, 2005). The inhibition of M-channels is thus excitatory, whereas their greater activation has an antiexcitatory, silencing effect. For example, the depression of M-currents turns single-spiking sympathetic neurons into tonically firing cells (Wang and McKinnon, 1995) and greatly induces spontaneous firing of hippocampal neurons

\section{Received Sept. 10, 2014; revised Nov. 3, 2014; accepted Dec. 15, 2014}

Author contributions: S.M.B., J.D.L., and M.S.S. designed research; S.M.B. performed research; S.M.B., F.S.C., J.D.L., and M.S.S. contributed unpublished reagents/analytic tools; S.M.B. and F.S.C. analyzed data; S.M.B. and M.S.S. wrote the paper.

This research was supported by National Institutes of Health (NIH) National Research Service Award 1F32NS079148-01 and NIH Training Grant T32-HL-07446-29 (2010-2012) awarded to S.M.B; NIH Grants R01-AG007218 to J.D.L.; and NIH National Institute of Neurological Disorders and Stroke Grants R01-NS-43394 and R01-NS065138 to M.S.S. We thank Pamela Reed for expert technical assistance. We also thank Shane Sprague and the Department of Neurosurgery Research Core for their assistance with the middle cerebral artery occlusion experiments.

This paper is in memory of Dr. Herbert Shapiro, late father of M.S.S., who passed away of stroke-related complications in 2012.

The authors declare no competing financial interests.

Correspondence should be addressed to Dr. Mark S. Shapiro, Department of Physiology/Neuroscience Program, University of Texas Health Science Center, 8403 Floyd Curl Drive, MS 7756, San Antonio, TX 78229. E-mail: shapirom@uthscsa.edu.

DOI:10.1523/JNEUROSCI.3805-14.2015

Copyright $\odot 2015$ the authors $\quad 0270-6474 / 15 / 352101-11 \$ 15.00 / 0$
(Lawrence et al., 2006). The critical effect of M-channels on neuronal excitability is underscored by epileptic seizures caused by inherited mutations, or transgenic suppression, of functional KCNQ2 and KCNQ3 channels in humans or mice, respectively (Biervert et al., 1998; Singh et al., 1998, 2008; Peters et al., 2005). In accordance with this, retigabine (RTG), which enhances M-channels by shifting their voltage dependence to more hyperpolarized membrane potentials, has emerged as a novel anticonvulsant drug (Main et al., 2000; Rundfeldt and Netzer, 2000; Wickenden et al., 2000; Miceli et al., 2008).

The most common form of stroke, acute ischemic stroke, produces a core area of damaged tissue close to an occluded blood vessel, which is surrounded by a penumbra of tissue at risk because of low vascular perfusion. These neurons die as a result of neurotoxic biochemical cascades initiated by reduced energy stores, failure of the $\mathrm{Na}^{+} / \mathrm{K}^{+}$pump, excess release of excitatory amino acids, and elevated $\left[\mathrm{Ca}^{2+}\right]_{\mathrm{I}}$ levels, resulting in neuronal hyperexcitability. Furthermore, excessive production of reactive oxygen species (ROS), such as superoxide free radicals and hydrogen peroxide $\left(\mathrm{H}_{2} \mathrm{O}_{2}\right)$, play critical roles in ischemic injury and damage, especially in the penumbral zone (Yamato et al., 2003; Cheng et al., 2004; Sugawara et al., 2004). Intriguingly, M-current is augmented by ROS such as $\mathrm{H}_{2} \mathrm{O}_{2}$ (Boscia et al., 2006; Gamper and Shapiro, 2006), perhaps representing a homeostatic neurobiological mechanism against cytotoxicity.

Previous work showed RTG and its predecessor, flupertine, to be neuroprotective during an oxygen/glucose deprivation model in organotypic hippocampal slices (Boscia et al., 2006; Gamper and Shapiro, 2006). Whereas that work was exciting, it represents an "in vitro" system that may not be the case in a living animal. Thus, we used two in vivo mouse stroke models. We discovered a cytoprotective role of M-channels during and after ischemic 
stroke, as well as the therapeutic possibility of M-channel openers against stroke-induced neurological deficits. We show that M-channel openers exert in vivo neuroprotective actions, which are most likely due to decreases in ischemia-induced hyperexcitability. We further demonstrate that these neuroprotective actions have a critical "therapeutic window" of drug delivery, making it a viable acute therapeutic target for the treatment of ischemic stroke. Finally, M-channel openers also largely prevented the stroke-induced impairment of motor function, thus limiting behavioral motor deficits.

\section{Materials and Methods}

Animals

Male C57BL/ 6 white albino mice ( $\sim 25 \mathrm{~g})$ were used in our experiments, given the known significant variation due to gender on stroke outcome in rodents. All animals were used, and none were eliminated once experiments had started, with only three deaths occurring after surgery. The mice were randomly allocated to receive drug treatment or vehicle and underwent stroke induction. Previous experiments indicated that the variability in infarct size was minimal and thus the power calculation, used by Zhao et al. (2006), showed that a minimum of eight animals per group were required to detect with $80 \%$ power and an $\alpha$ of 0.05 . The age of the mice ranged from 4 to 6 months and were obtained from Charles River Laboratories. Mice colonies were bred and housed at the University of Texas Health Science Center at San Antonio animal facilities under standard conditions on a $12 \mathrm{~h}$ light/dark cycle with food and water available ad libitum. Animal procedures were performed in accordance with the Institutional Animal Care and Use Committee at the University of Texas Health Science Center at San Antonio, and were in compliance with the National Institutes of Health Guide for Care and Use of Laboratory Animals.

\section{Surgical procedures}

Focal ischemia by photothrombosis. Mice were initially anesthetized using $3 \%$ isoflurane with $100 \%$ oxygen and maintained at $1.5 \%$ isoflurane, which was administered through a nosecone. The depth of anesthesia was carefully monitored and regulated according to vital signs, pinch withdrawal, and eye blinks. Body temperature was maintained at $37^{\circ} \mathrm{C}$ by a feedback-controlled heating pad (T/Pump, Gaymar Industries). Their scalp was shaved and incised down the midline, and the scalp was exposed and cleaned. A stainless steel ring, which was attached to a stereotaxic frame, was glued (VetBond, $3 \mathrm{M}$ ) to the scalp. A small portion of the skull, overlaying the somatosensory cortex, was thinned (between $\sim 1$ and $\sim 3 \mathrm{~mm}$ from bregma, and $2-4 \mathrm{~mm}$ lateral) using a variable-speed electric drill (Fine Science Tools), and was further thinned using a surgical blade to a final thickness of $\sim 50 \mu \mathrm{m}$ to create the thin-skull cranial window.

A solution containing $2.5 \mathrm{~mm} \mathrm{KCl}, 1.25 \mathrm{~mm} \mathrm{NaH}_{2} \mathrm{PO}$, $2 \mathrm{~mm} \mathrm{MgCl}_{2}$, $10 \mathrm{~mm}$ glucose, and $26 \mathrm{~mm} \mathrm{NaHCO}_{3}, \mathrm{pH} 7.4$, was maintained on the cortical surface. After a cranial window was made, mice were transferred to the microscope stage and used for induction of a photothrombosis. After thrombosis, the stainless steel ring was carefully removed from the skull and the scalp was sutured (6-0 silk suture, Ethicon).

Cortical infarcts designed to mimic a human transient ischemic attack (TIA) were produced by transcranial illumination of focused laser light onto the surface of the brain of mice tail-vein injected with the photosensitive dye, Rose Bengal (RB). The photochemical reaction of RB activates a tissue factor that triggers an intrinsic coagulation cascade, producing an ischemic lesion that is pathologically relevant to clinical stroke. Mice were given a $0.1 \mathrm{ml}$ tail-vein injection of sterilized RB (Sigma) in aCSF at $20 \mathrm{mg} / \mathrm{ml}$. Arteries were identified by the direction of blood flow and were followed downstream to locate arterioles. Arterioles of 20-30 mm were targeted and exposed to light from a 561-nm laser through a 0.8 numerical aperture, $40 \times$ water-immersion objective (Nikon) until clot formation and/or after $20 \mathrm{~min}$ of light exposure. Mice were sutured and allowed to recover in an incubator before being returned to their home cages. Drugs were delivered through the tail vein at different time intervals.
Focal ischemia by middle cerebral artery occlusion and drug delivery. Infarcts were induced using a temporary left common carotid artery/ middle cerebral artery occlusion (MCAo). The intraluminal monofilament model of middle cerebral artery occlusion involves the insertion of a surgical filament into the external carotid artery and the threading of the filament forward into the flow, with subsequent brain infarction in the MCA perfused area. The suture is removed after $1 \mathrm{~h}$, and reperfusion is achieved resulting in transient MCAo. Core body temperature was maintained at $37^{\circ} \mathrm{C}$ by a heating pad (T/Pump, Gaymar Industries) during ischemia and the first hour of reperfusion. Mice were sutured and allowed to recover in an incubator before being returned to their home cages. Drugs were delivered through the tail vein at different time intervals.

\section{Neuronal lesion evaluation and quantification following stroke}

The infarct area after photothrombotic and MCAo stroke models was determined by 2,3,5-triphenyltetrazoluim chloride (TTC) at staining $24 \mathrm{~h}$ or $5 \mathrm{~d}$ poststroke. Infarct quantification was made by tracing the infarct zone of a high-contrast image of slices directly scanned with a high-resolution flatbed scanner (Scanjet G4050, Hewlett-Packard). To ensure that the same ischemic and normal areas of the brain were available, the same relative slice was used for each brain, and only those brains that had infarcts extending throughout the thickness of the slice and into a consecutive slice were included in the study, although only one slice was used for analysis. All scans were made at 4500 dpi with no color correction or image enhancement. Infarct area calculations (in square millimeters) were conservative in that only a clearly defined absence of TTCstained areas were considered the necrotic core area, and "pink" or more compromised areas were designated as healthy tissue for the purpose of analysis. Each slice was measured on the caudal and rostral sides three times each, and an average area of necrotic death for the slice was calculated using Image software and mosaicJ plug-in. Any areas not clearly considered part of the necrotic core were measured and subtracted from the average area to ensure a conservative approach to the measurement of the necrotic core (found only in the MCAo model). Mice were killed by cervical dislocation, and their brains were removed and then placed in ice-cold HBSS for $3 \mathrm{~min}$. The brain was subsequently transferred to a precision brain slicer, sliced into $1 \mathrm{~mm}$ sections, and immersed in $2 \%$ TTC for $5 \mathrm{~min}$ at $37^{\circ} \mathrm{C}$. The sections were fixed in $10 \%$ buffered formaldehyde solution overnight at $4^{\circ} \mathrm{C}$. TTC is a colorless dye that stains healthy brain tissue red when reduced by the mitochondrial enzyme succinyl dehydrogenase (Bederson et al., 1986). The absence of staining in necrotic tissue is then used to determine the area of a brain infarction. TTC staining is a postmortem basic standard in the field and served as our basic assessment tool for measuring infarct size.

\section{Statistical analysis}

All data were analyzed using ImageJ and Systat SigmaPlot version 12.5 software. Quantitative data were expressed as the mean \pm SEM. Statistical comparisons were performed by one-way ANOVA followed by pairwise multiple-comparison Holm-Sidak test. Differences with $p<0.05$ were considered to be significant.

\section{Reagents and drug delivery}

In control experiments, neither laser illumination nor Rose Bengal injection $(20 \mathrm{mg} / \mathrm{ml}$; Sigma-Aldrich) itself led to clot formation. RTG (10.5 $\mathrm{mg} / \mathrm{kg}$; AdooQ Bioscience) was coinjected with Rose Bengal into the tail vein at the time of stroke or at designated varying time points. NH29 ( $10.0 \mathrm{mg} / \mathrm{kg}$; from Bernard Attali, Tel Aviv University, Tel Aviv, Israel) or QO-58 (0.01 mg/kg; from Hailin Zhang, Hebei Medical University, Hebei, People's Republic of China) were coinjected with RB into the tail vein at the time of stroke or at designated varying time points. The M-channel blocker XE991 (3.0 mg/kg; Tocris Bioscience) was also coinjected with RTG and/or RB at the time of the stroke. RTG administered after stroke was dissolved in aCSF.

\section{SDS-PAGE and Western blotting}

Brain tissue samples removed $24 \mathrm{~h}$ poststroke were flash frozen and stored at $-80^{\circ} \mathrm{C}$ until all samples were collected. Samples were homogenized in PBS, and supernatants were collected for 12.5\% SDS-PAGE. 
Five microliters of the homogenized sample was loaded into each well used. The sample was prepared from taking a $1 \times 1 \mathrm{~mm}$ square of tissue from the penumbral area of the brain slice. Each slice generated two samples, and, with three mice per experimental condition, there were therefore a total of six samples. A loading control dose of $\beta$-actin was used to ensure that the same amount of protein was used for all treatment conditions in the Western blot, and the data for CD40L were normalized to $\beta$-actin for quantitative measures. The standard BCA protein assay could not be used since it uses a color development reaction for analysis and our brain slices were stained with TTC to locate the stroke core and penumbral areas. Gels were run at $150 \mathrm{~V}$ for $90 \mathrm{~min}$ and then transferred to nitrocellulose transfer paper for $45 \mathrm{~min}$ at $35 \mathrm{~mA}$. The nitrocellulose membrane was labeled by a monoclonal anti-CD40 primary antibody (1:1000; Abcam) overnight at $4^{\circ} \mathrm{C}$ after three washes with TBS- $\mathrm{T}$. Then membranes were incubated in goat anti-mouse secondary antibody (1: 2000; Sigma) for $45 \mathrm{~min}$ at room temperature in 5\% nonfat milk dissolved in TBS-T, followed by enhanced chemiluminescence (GE Healthcare). Blots were then washed in TBS-T and put into monoclonal primary antibody $\beta$-actin (1:1000; Sigma) and mouse secondary antibody (1:2000; Sigma) for $45 \mathrm{~min}$ at room temperature in 5\% nonfat milk dissolved in TBS-T. A total of 96 mice were used with 3 mice used per experiment.

\section{Neurological deficit behavior assessment}

Behavioral tests were performed only on photothrombotic mice due to profoundly severe motor impairment in MCAo stroked mice. All tests were performed in a soundproof room with a neutral environment in a blinded study. The animals were tested $24 \mathrm{~h}$ postoperatively.

In the balance beam test (Stanley et al., 2005), mice were trained on a balance beam ( $104 \mathrm{~cm}$ long $\times 1.3 \mathrm{~cm}$ wide $\times 54.5 \mathrm{~cm}$ high) by placing each mouse on the balance beam at one end and requiring it to traverse the beam three times in one direction before any surgical experiments were performed to obtain optimal performance (see Fig. $5 B$ ). If the mouse stopped midway on the beam, it was gently nudged on its haunches to reinitiate movement during the training phase. Once the mouse made three complete trips across the beam in a single direction, three consecutive trials were recorded and scored for behavior. The total number of foot slips was counted from digital recordings for each trial and then averaged across the three trials for each mouse. For recording, a camera was positioned at a slight ventral angle so that all four limbs could be simultaneously recorded. First, each balance beam test was performed, and then the ladder dexterity test.

In the ladder dexterity test (Metz and Whishaw, 2002), a horizontal ladder rung walking test apparatus $(1 \mathrm{~m}$ long $\times 3 \mathrm{~mm}$ wide $\times 19 \mathrm{~cm}$ high) was placed $30 \mathrm{~cm}$ above the ground, and the rungs were placed $2 \mathrm{~cm}$ apart from each other (see Fig. 5C). Mice were trained on the ladder by placing each mouse at one end and requiring them to traverse the ladder three times in one direction. As described for the balance beam, a mouse that stopped was gently nudged to reinitiate movement. Once the mouse made three complete trips during the training phase, three consecutive trials were recorded and scored for the total number of foot slips, stumbles, and/or falls, which were counted from digital recordings for each trial, and then averaged across the three trials for each mouse. A camera was positioned at a perpendicular angle to capture foot slips through the ladder rungs (see Fig. 5B, red arrow). Experimental groups consisted of the following: (1) controls (no surgery), (2) sham surgery (skull thinning and RB injection, but no irradiation), (3) stroke (with RB injection only), (4) stroke with RTG, (5) stroke with XE991, (6) stroke with NH29, (7) stroke with QO-58, and (8) stroke with RTG plus XE991 coinjection (see Fig. $5 A$ ). For cohorts $2-8$, each mouse was tested before undergoing the stroke (or sham stroke). Thus, in addition to the control cohorts for the experimental animals, each mouse served as its own control.

\section{Results}

\section{M-channel openers decrease acute transient cerebral infarcts} in mice

The first aim of our study was to investigate the neural protective efficacy of M-channel openers against ischemic injury. In those experiments, we tested the effects of M-channel openers RTG,
NH29, and QO-58, as well as the blocker XE991, on infarct size in the parietal cortex. All M-channel openers were administered as single doses, applied at concentrations previously used in other studies, and predicted to exert a maximal effect on the channels. Thus, we used a pharmacological approach, which is also more directly relevant to the clinic. We mostly used the photothrombotic stroke model, which may correlate with TIAs often seen in humans. This is a minimally invasive technique and, thus, was our primary in vivo model. In brief, an acute cerebral infarction was induced in a small region in the mouse parietal cortex by occluding a blood vessel using the photosensitive dye RB and laser-induced photothrombosis. The skull of the mouse was thinned and irradiated with green laser light $(561 \mathrm{~nm})$ for $\sim 10$ min after tail vein injection of RB. When RB is excited, singlet oxygen molecules that locally damage the blood vessel walls are formed, which ultimately triggers a thrombosis (Watson et al., 1985). We used this paradigm to visualize RB-induced cerebral infarctions. In the photothrombotic stroke model, the infarct size evolves such that maximal cell death effect is ultimately reached by 1-2 d after stroke (Braun et al., 1996; Zheng et al., 2010). Given that RTG can readily cross the blood-brain barrier, free concentrations in the brain are assumed to be those of plasma concentrations. The M-channel drugs used here are assumed to cross the stroke-induced breakdown of the blood-brain barrier, a disruption that has been shown by earlier studies focused on astrocytes (Longa et al., 1989; Zheng et al., 2010).

Figure 1 illustrates the effect of M-channel openers and the blocker XE991 on the lesion sizes of brains removed $24 \mathrm{~h}$ after photothrombotic stroke. M-channel openers administered at the time of stroke significantly reduced the infarct size (RTG: $1.08 \pm$ $\left.0.03 \mathrm{~mm}^{2}, p=0.001, n=8\right)$; NH29: $0.98 \pm 0.13 \mathrm{~mm}^{2}, p=0.001$, $n=5$; and QO-58: $\left.0.98 \pm 0.24 \mathrm{~mm}^{2}, p=0.001, n=5\right)$, compared with the stroke control group $\left(2.00 \pm 0.03 \mathrm{~mm}^{2}, n=5\right)$. On the other hand, the administration of XE991 significantly enhanced lesion size $\left(3.93 \pm 0.32 \mathrm{~mm}^{2}, p<0.001, n=6\right)$. Coadministration of RTG plus XE991 resulted in a lesion size that was larger than that of controls $\left(3.93 \pm 0.21 \mathrm{~mm}^{2}, p<0.001, n=\right.$ 6 ), indicating that the effect of RTG was due to effects on M-channels. Additionally, NH29 and QO-58 had effects that were indistinguishable from those of RTG, suggesting that upregulation of $\mathrm{M}$-channels by openers, regardless of the compound, results in reductions in the infarction area induced by stroke. Thus, simultaneous administration of M-channel openers at the onset of ischemia significantly reduced the infarct area induced by the photothrombotic stroke.

\section{M-channel openers decrease MCAos in mice}

To further investigate the neuroprotective effects of M-channel openers on lesion size after more severe cerebrovascular events, we used the catastrophic stroke model, MCAo, which is known for severe debilitating effects and large areas of cell death. MCAo is the most frequently used model in translational stroke research involving catastrophic events resulting in cell death of almost a full hemisphere (Longa et al., 1989). As indicated in Figure 2, all three M-channel openers significantly decreased infarct volume after 60 min of occlusion and then reperfusion with brains removed $24 \mathrm{~h}$ poststroke. Infarct size was significantly reduced in conditions of stroke plus RTG administration $\left(11.7 \pm 0.4 \mathrm{~mm}^{2}\right.$, $p<0.001, n=6)$, stroke plus NH29 administration (11.0 \pm 0.2 $\mathrm{mm}^{2}, p<0.001, n=6$ ), and stroke plus QO-58 administration $\left(11.6 \pm 0.3 \mathrm{~mm}^{2}, p<0.001, n=6\right)$, compared with the RB-only control group (16.6 $\left.\pm 0.2 \mathrm{~mm}^{2}, n=5\right)$. In summary, using the 
A
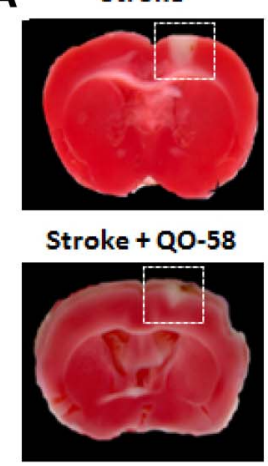

Stroke + XE991

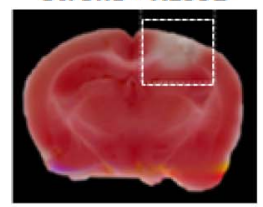

Stroke + RTG

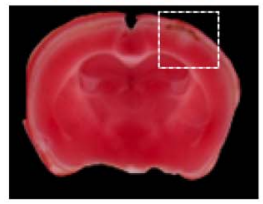

Stroke $+\mathrm{NH} 29$

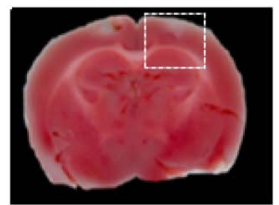

Stroke + XE991 + RTG

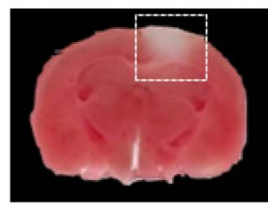

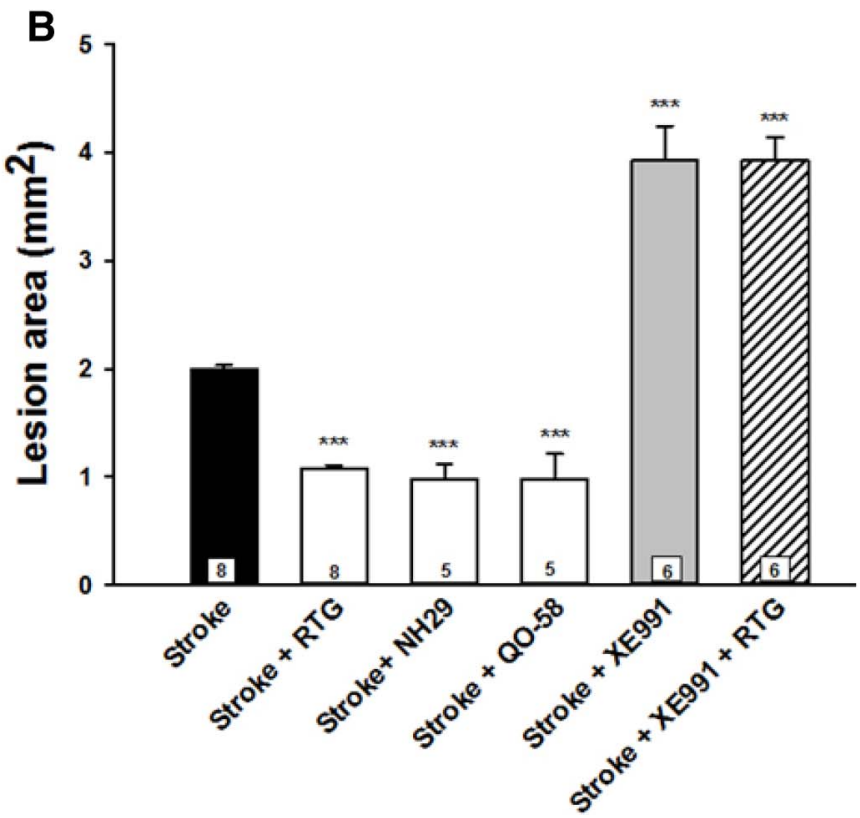

Figure 1. M-channel openers decrease acute transient cerebral infarcts in mice. $A$, Brains were removed $24 \mathrm{~h}$ poststroke and stained for live mitochondria at the time of sacrifice, using TTC staining. Necrotic tissue is identified in each panel (dashed rectangles) as the absence of red staining, indicating non-metabolically active mitochondria at the time of sacrifice. $\boldsymbol{B}$, Bars show the average lesion area for stroke control, stroke plus retigabine-treated, stroke plus NH29-treated, stroke plus Q0-58-treated, stroke plus XE991-treated and stroke plus RTG plus XE991-treated animals. Means are calculated from at least five mice for each point. All drugs were injected into the tail vein at the time of the stroke. ${ }^{* *} p<0.001$.

A

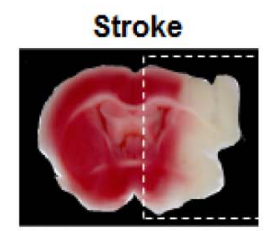

Stroke + NH29

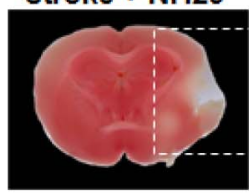

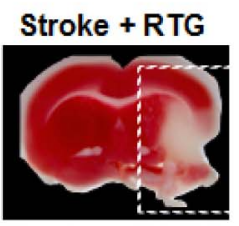

Stroke + Q0-58

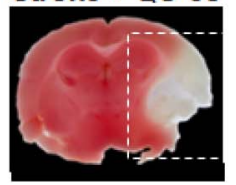

B

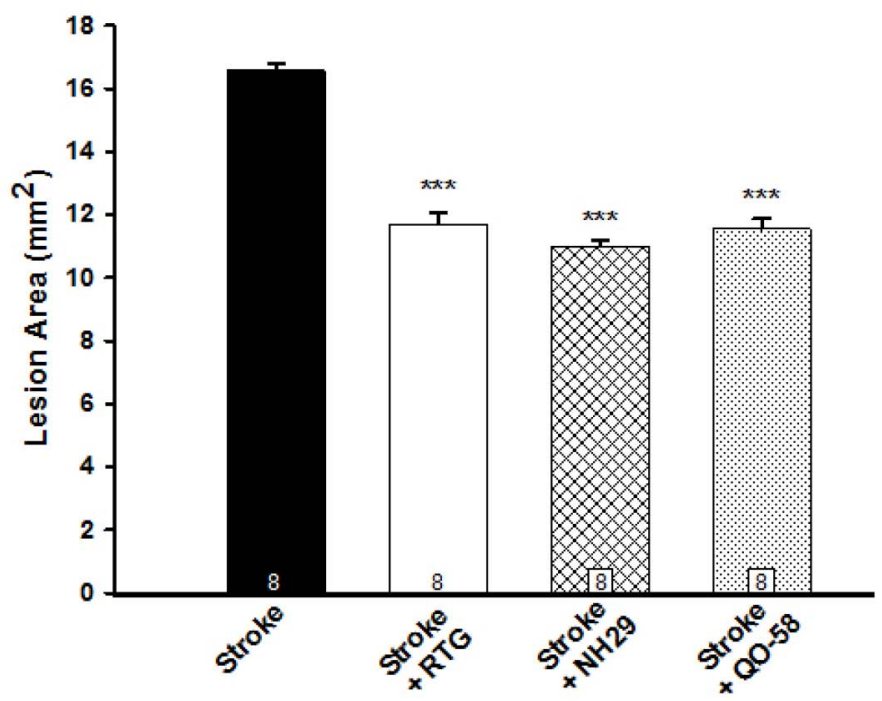

Figure 2. M-channel openers decrease middle cerebral artery occlusion infarcts. $A$, Images of brains removed and sliced $24 \mathrm{~h}$ poststroke and TTC stained from stroke mice, or from those stroked and injected with RTG, NH29, or Q0-58 into the tail vein at the time of the stroke. $B$, Quantification of lesion size in the MCAo model, with reperfusion after 60 min. Bars show summarized data. $N=$ 8 mice. ${ }^{* * *} p<0.001$.

more catastrophic MCAo stroke model, we also showed a significant decrease in necrotic lesion size with the administration of RTG via the tail vein during reperfusion after a 60 min occlusion, as well as by administration of the structurally distinct compounds NH29 and QO-58. Thus, increasing the opening of $\mathrm{M}$-channels results in significant decreases in lesion size after either a modest or a catastrophic ischemic event. We focused all further experiments on one channel opener, RTG. The advantage of using RTG in our studies is that it is available in the clinic in the U.S. under the trade name ezogabine and, thus, is probably most directly clinically relevant.
Therapeutic time window of effectiveness for M-channel openers

The possible clinical relevance of retigabine treatment was investigated by evaluating normalized infarct size following both photothrombotic and MCAo models at 1, 3, or $6 \mathrm{~h}$ poststroke, with brains removed at $24 \mathrm{~h}$ poststroke (Fig. 3 ). Figure $3 A$ shows TTCstained brain slices obtained after either the photothrombotic (Fig. 3A, top) or the MCAo model (Fig. 3A, bottom). In strokeonly animals, significantly larger infarctions developed when compared with M-channel opener-treated animals or when RTG administration was delayed for up to $3 \mathrm{~h}$. Delayed administration 
A
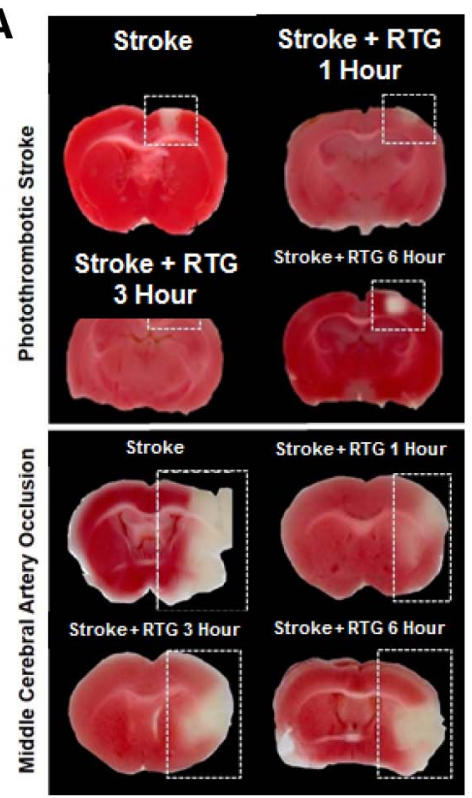

B

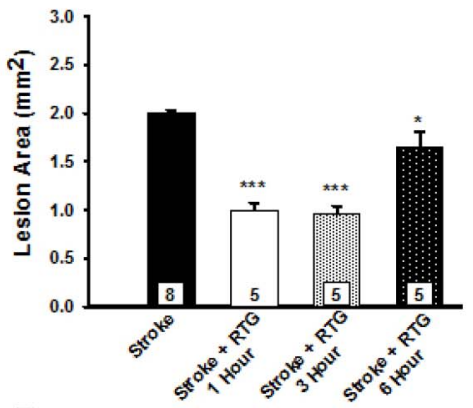

D

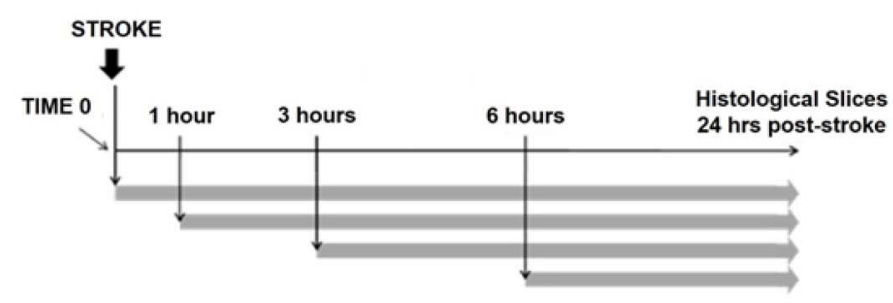

Figure 3. Therapeutic time window of effectiveness for $\mathrm{M}$-channel openers. $\boldsymbol{A}$, Brains were removed $24 \mathrm{~h}$ poststroke and stained for live mitochondria at the time of sacrifice, using $T \mathrm{TT}$ staining. Necrotic tissue is identified in each panel (dashed rectangles) as the absence of red staining, indicating non-metabolically active mitochondria at the time of sacrifice. $\boldsymbol{B}$, Bars show the average lesion area for photothrombotic stroke, stroke plus retigabine treatment after $1 \mathrm{~h}$, stroke plus retigabine treatment after $3 \mathrm{~h}$, and stroke plus retigabine treatment after $6 \mathrm{~h}$. $\boldsymbol{C}$, Bars show the average lesion area for MCAo stroke, stroke plus retigabine treatment after $1 \mathrm{~h}$, stroke plus retigabine treatment after $3 \mathrm{~h}$, and stroke plus retigabine treatment after $6 \mathrm{~h}$. Means are calculated from at least five mice for each point. $\boldsymbol{D}$, All drugs were injected into the tail vein at various times after the stroke, as indicated by the arrows. ${ }^{*} p<0.05,{ }^{* * *} p<0.001$.

of RTG up to $3 \mathrm{~h}$ resulted in the same significant reduction in lesion size response as if it were given at the time of stroke for both stroke models (Fig. $3 B, C$ ). For the photothrombotic stroke, infarct size was significantly reduced in stroke plus RTG administration at $1 \mathrm{~h}\left(0.99 \pm 0.07 \mathrm{~mm}^{2}, p<0.001, n=5\right)$, stroke plus RTG administration at $3 \mathrm{~h}\left(0.96 \pm 0.08 \mathrm{~mm}^{2}, p<0.001, n=5\right)$, and stroke plus RTG administration at $6 \mathrm{~h}\left(1.65 \pm 0.15 \mathrm{~mm}^{2}, p=\right.$ $0.014, n=5)$, when compared with the control group ( $2.0 \pm 0.1$ $\left.\mathrm{mm}^{2}, n=8\right)$. For the MCAo stroke, the infarct size was significantly reduced in stroke plus RTG administration at $1 \mathrm{~h}(11.1 \pm$ $\left.0.7 \mathrm{~mm}^{2}, p<0.001, n=5\right)$, stroke plus RTG administration at $3 \mathrm{~h}\left(11.3 \pm 0.5 \mathrm{~mm}^{2}, p<0.001, n=5\right)$, and stroke plus RTG administration at $6 \mathrm{~h}\left(15.5 \pm 0.2 \mathrm{~mm}^{2}, p=0.008, n=6\right)$, when compared with controls $\left(16.6 \pm 0.6 \mathrm{~mm}^{2}, n=6\right)$. For both stroke models, RTG administered $6 \mathrm{~h}$ after the stroke had reduced efficacy compared with RTG administered at 0,1 , or $3 \mathrm{~h}$ poststroke, but still significantly less than control animals, indicating a critical time window closer to $3 \mathrm{~h}$ than $6 \mathrm{~h}$. These results suggest that the impact of RTG on lesion size and brain injury is dependent on the time of administration. Up to $6 \mathrm{~h}$ poststroke, M-channel openers were neuroprotective for cells in the penumbra region, whose viability would otherwise be metabolically compromised and thus would mostly likely not survive.

\section{Photothrombotic clot stability}

To test how long after the stroke onset the protective mechanism of RTG could be observed, experiments were performed to directly measure the size of photothrombotic lesions in brain slices after 1 and $5 \mathrm{~d}$ poststroke (Fig. 4). Consistent with previous experiments shown in this study, we found that RTG administered immediately after the photothrombosis resulted in significantly reduced brain infarcts (RTG: $0.93 \pm 0.13 \mathrm{~mm}, p<0.001, n=5$ ) when compared with controls (stroke: $2.04 \pm 0.11 \mathrm{~mm}, n=5$ ) and that the reduction in infarct area was still significant in ani- mals $5 \mathrm{~d}$ after photothrombosis (stroke: $2.44 \pm 0.34 \mathrm{~mm}, n=5$; RTG: $0.92 \pm 0.07 \mathrm{~mm}, n=5 ; p<0.001)$. Furthermore, the infarct size was shown to significantly increase from day 1 to day 5 in controls $(p=0.008)$, whereas the infarct size after stroke plus RTG administration did not significantly change $(p=0.485)$ over the same time frame. Thus, the clot is stable over time, and the effect of RTG on lesion size when administered in the therapeutic window shows consistent results.

\section{M-channel opener retigabine modulates CD40L as a cell injury marker for brain infarcts}

CD40 is a $45-50 \mathrm{kDa}$ membrane protein of the tumor necrosis factor receptor family, which is important in cellular signaling, and is an early important contributor to tissue necrosis during acute ischemic infarction, with activation playing a key role in the inflammatory response. Various immune cells including B lymphocytes, T cells, monocytes, macrophages, and activated platelets have the capability to express CD40, in addition to many other cell types (Pamukcu et al., 2011). CD40 interaction with its ligand CD40L has been shown to be involved in inflammation and thrombosis, as well as to play a crucial role in cellular and humoral immune responses (Schönbeck et al., 1997). Additionally, CD40 expression can be induced by different proinflammatory stimuli such as IL-1, IL-3, and IL-4, as well as other factors. They usually appear on the cell surface within 6-12 $\mathrm{h}$ and remain for 24-72 h. The role of CD40-CD40L appears to be to induce endothelial cells to secrete chemokines and express adhesion molecules at the site of injury, and to recruit leukocytes. In Figure 5 , we analyzed Western blots of brain tissue lysates exposed to anti-CD40 antibodies to measure the amount of CD40L after the photothrombotic stroke for stroke-only and RTG-treated mice. Brains were removed $24 \mathrm{~h}$ poststroke. We predicted that strokeonly mice would have markedly increased levels of CD40Lexpressing cells compared with control mice, and that this would correlate with our histological data. 

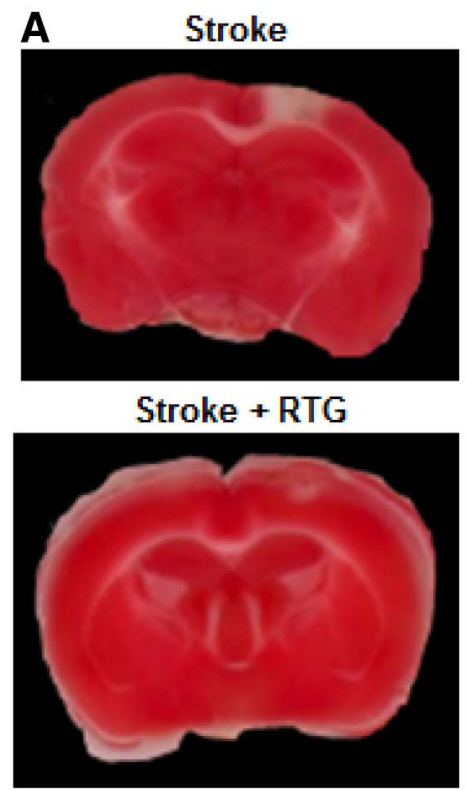

B

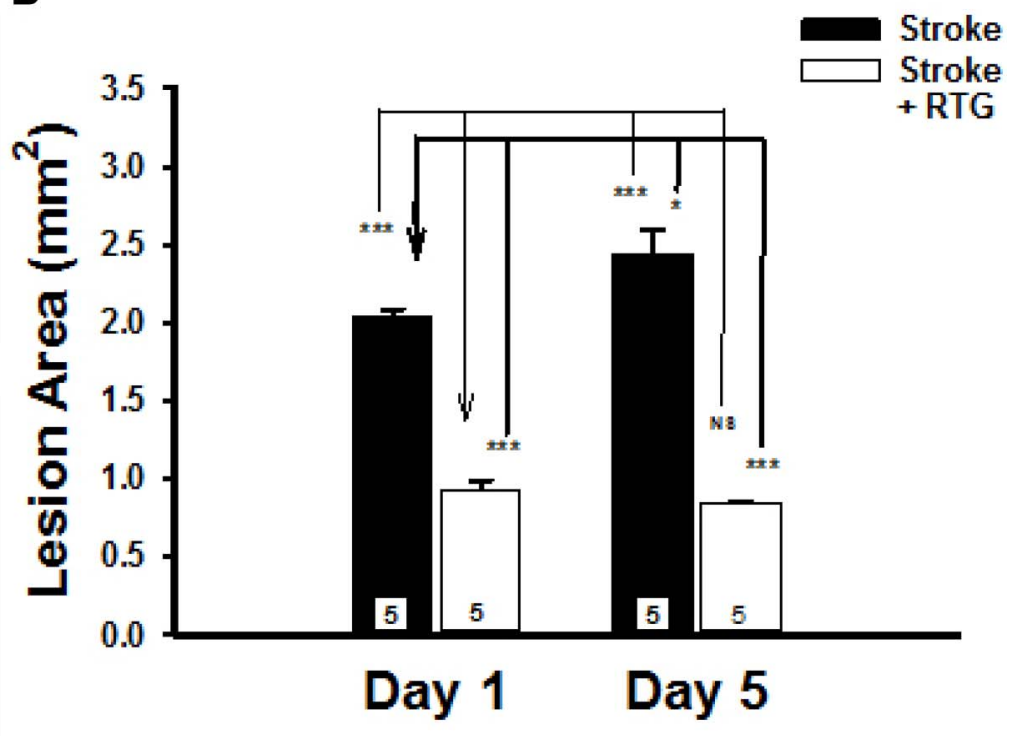

Figure 4. Photothrombotic clots remain after $5 \mathrm{~d}$. $\boldsymbol{A}$, Images of brains removed and stained with TTC at $5 \mathrm{~d}$ or $24 \mathrm{~h}$ poststroke from stroke-only mice or from mice stroked and injected with RTG into the tail vein at the time of stroke. $\boldsymbol{B}$, Bars show the average size of lesions at 1 and $5 \mathrm{~d}$ after the photothrombotic stroke. Means are calculated from five mice for each time point. ${ }^{*} p<0.05$, ${ }^{* * *} p<0.001$. NS, Not significant.

Figure $5 A$ shows Western blot expression of CD40L in which we can detect clear CD40L-reactive bands at $\sim 45 \mathrm{kDa}$. No CD40L was detectable in the nonstroked control mice or the contralateral hemisphere of stroked mice, compared with the ipsilateral hemisphere of stroke-only and RTG-treated photothrombotically stroked mice. Furthermore, the blot visually shows that untreated mice had an increased amount of CD40L, compared with RTG-treated mice for all time points. Quantitative analysis of the band intensity shown in Figure $5 B$ shows that at $24 \mathrm{~h}$ after stroke the amount of CD40L was significantly decreased when RTG is administered during the therapeutic window of $0 \mathrm{~h}(p<0.001, n=6)$ and $3 \mathrm{~h}(p<0.001, n=6)$, but was not significant at $6 \mathrm{~h}$ after stroke $(p=0.58, n=6)$. Additionally, when RTG was administered during the $0-6 \mathrm{~h}$ therapeutic window and levels were sampled periodically over $5 \mathrm{~d}$, there was a significant difference over time in the CD40L levels when compared with stroke-only animals at the same time points. Quantitative analysis of CD40L band intensity in Figure $5 C$ shows that at $1 \mathrm{~d}(p<0.001, n=6), 3 \mathrm{~d}(p<0.001, n=6)$, and $5 \mathrm{~d}(p<0.001$, $n=6)$ poststroke the amount of CD40L was significantly reduced when compared with untreated animals at the same time points. Thus, pharmacological M-current enhancement ameliorates the inflammatory response that is central to brain injury after a stroke.

\section{M-channel openers improves poststroke motor function in mice}

With clear evidence of the efficacy of M-channel openers to reduce infarct size and to moderate the inflammatory response following strokes, we next probed for corresponding efficacy in reducing or preventing deficits in motor coordination commonly experienced after a stroke (Brima et al., 2013). As well accepted assays for motor coordination, we used the balance beam and ladder dexterity assays. Since MCAo is a commonly used model of catastrophic stroke, we attempted to look for a behavioral deficit after an MCAo event. However, due to the severe nature of the stroke outcome and the resulting complete inability of the mouse to perform the tasks on the balance beam and ladder dexterity tests, we did not use MCAo-stroked mice in behavioral assays. In many cases, these mice could not traverse the balance beam without falling off or scale the ladder in the ladder dexterity test without falling through; consequently, further testing after MCAo strokes was stopped, and we focused on the photothrombotic stroke model for behavioral testing (Fig. 6). This model has been shown to produce both motor and cognitive impairments in many other studies (Brima et al., 2013). Casual observation of the mice after lesion induction did not reveal any profound behavioral differences. They appeared to be unimpaired in their movements and readily ate after a few hours when placed back into their original cages. Behavioral testing consisted of watching for foot slips, defined as mis-steps, on behavioral apparatuses. Figure $6 \mathrm{~A}-\mathrm{C}$ outlines the mouse groups involved in our behavioral testing and shows images of mice performing these two tests.

\section{Balance beam test}

To ensure that none of the M-channel openers, or RB, affect motor coordination on the balance beam test, we first assayed for behavioral effects before stroke experimentation. We found that RB only $(p=0.504, n=10)$, RTG $(p=0.961, n=11)$, NH29 $(p=0.975, n=6)$, or QO-58 $(p=0.972, n=6)$ did not show any significant difference in behavior, compared with controls. However, mice that were administered either XE991 $(p<0.001, n=$ 8) or XE991 plus RTG ( $p<0.001, n=10)$ showed a significant increase in the average number of mis-steps compared with the control group, suggesting that hyperexcitability induced by M-channel blockade itself affects motor coordination.

Next, we examined the effect of drugs on behavioral responses using the balance beam test after photothrombotic stroke (Fig. $6 D$ ). In comparing control mice (no operation or drugs, $n=16$ ) with sham mice (operation only, $n=10$ ), we found no statistical difference in behavior $(p=0.91)$. However, the stroked mice displayed much slower progress on the balance beam, with significantly more mis-steps (RB-injection only: $p<0.001, n=8$; Movie 1). Remarkably, stroked mice that were administered 


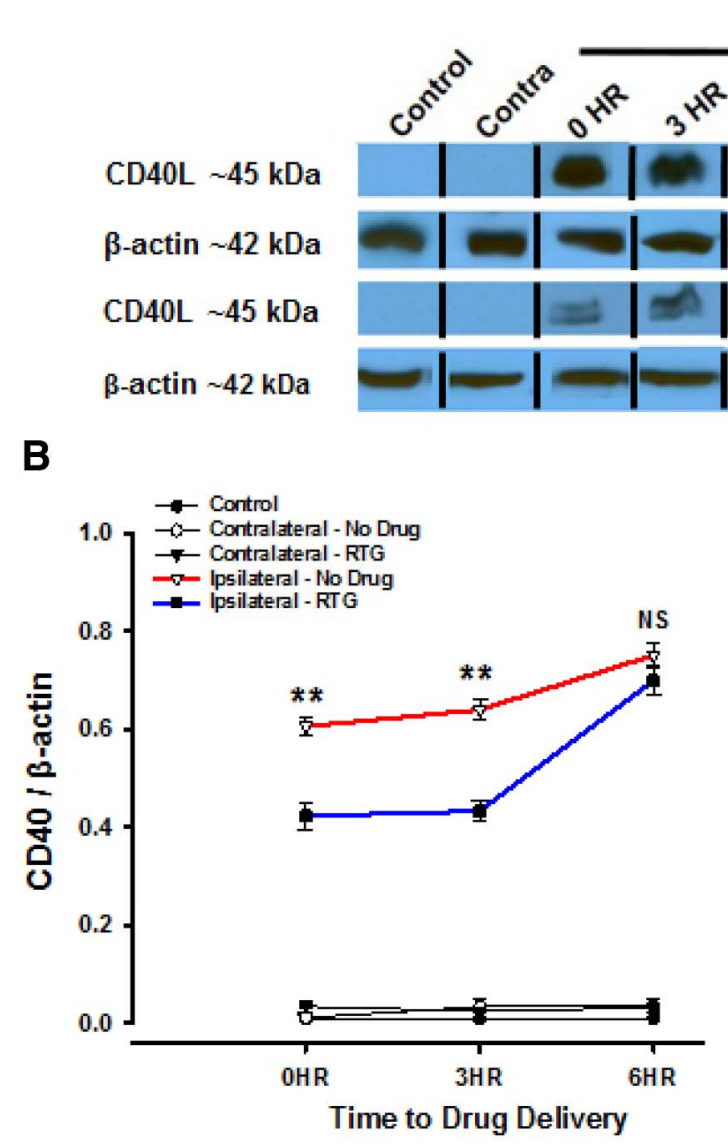

Ipsilateral

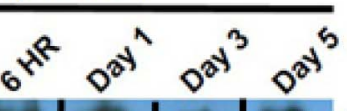

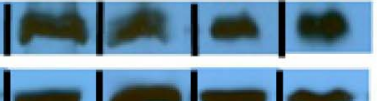

No Drug

Loading Control

Retigabine

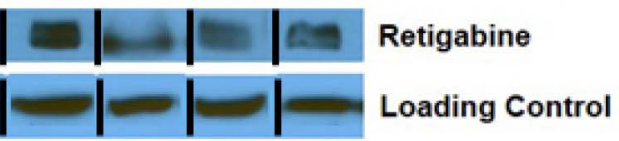

C $\rightarrow$ - Control

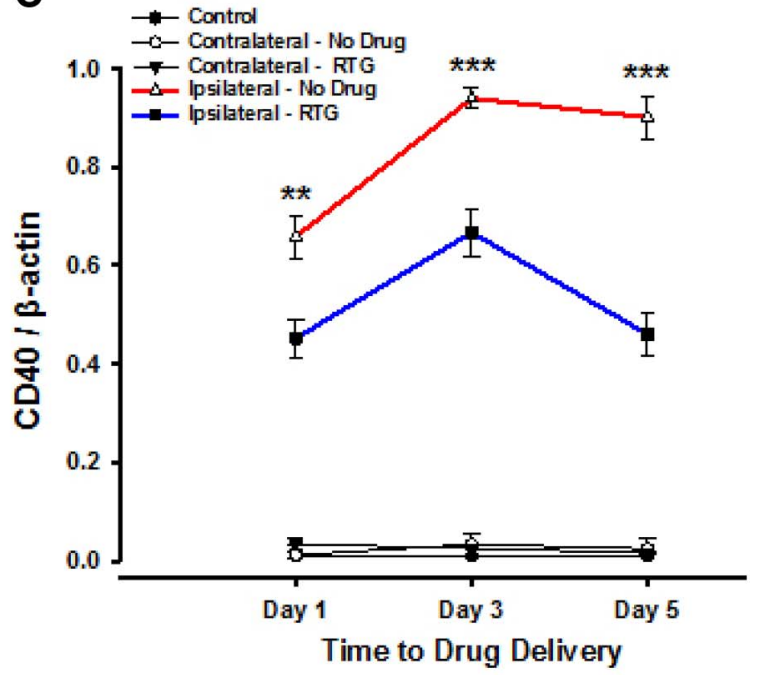

Figure 5. The M-channel opener retigabine modulates CD40L as a cell injury marker. $A$, Western blotting analysis with anti-CD40 was performed to quantify levels of CD40L in infarct plus penumbra compared with normal contralateral hemispheres. CD40L was used to visualize the ischemic injury response with drug delivery at time points 0,3 , and $6 \mathrm{~h}$ poststroke (analysis conducted $24 \mathrm{~h}$ after drug delivery), as well as on days 1,3, and 5 (with drug administered at $0 \mathrm{~h}$ ). The relative expression of CD40 $\mathrm{L}$ protein was determined by normalization to $\beta$-actin. Western blots are representative of multiple independent experiments. $N=6 . B$, Quantitative analysis of $C D 40$ protein normalized to $\beta$-actin shows significant differences when RTG was administered during the therapeutic window. C, Quantitative analysis of CD40 protein normalized to $\beta$-actin of RTG given at $0 \mathrm{~h}$ with sampling of CD40L over $5 \mathrm{~d}$ shows a significant decrease with RTG administration and significant changes over time. Line graphs show the relative expression of CD40 protein. The most relevant statistically significant differences are shown between ipsilateral-no drug and ipsilateral-retigabine time points. All drugs were injected into the tail vein at various designated time points. Data are presented as the mean \pm SEM. ${ }^{*} p<0.05$, ${ }^{* *} p<0.01$, ${ }^{* * *} p<0.0001$.

three different M-channel openers showed no significant differences in behavior, compared with the sham controls (stroke plus RTG administration: $p=0.43, n=6$; stroke plus NH29 administration: $p=0.72, n=6$; and stroke plus QO-58 administration: $p=0.69, n=6$ ), and thus performed significantly better than stroked mice not administered any of the M-channel openers (stroke plus RTG administration: $p<0.001, n=6$; stroke plus NH29 administration: $p<0.001, n=6$; stroke plus QO-58 administration: $p<0.001, n=6$ ). Indeed, for all three openers, the performance of the mice on the balance beam was indistinguishable from the controls or shams. Conversely, mice that had undergone stroke plus XE991 administration $(p<0.001, n=6)$ and stroke plus XE991 plus RTG administration $(p<0.001, n=10)$ performed very poorly on the balance beam test (Fig. $6 D$ ), with much greater numbers of mis-steps, stumbles, and long hesitations, consistent with fear-like responses (Movie 1).

\section{Ladder dexterity test}

To ensure that none of the M-channel openers, or RB, affect motor coordination on the ladder dexterity test, we first assayed for behavioral effects before stroke experimentation. We found that RB only ( $p=0.504, n=10)$, RTG $(p=0.961, n=11)$,
NH29 ( $p=0.975, n=6)$, or QO-58 $(p=0.972, n=6)$ did not show any significant differences in behavior, compared with controls. However, mice administered either XE991 $(p<0.001, n=$ 8 ) or XE991 plus RTG ( $p<0.001, n=10)$ showed a significant increase in the average number of mis-steps compared with the control group, suggesting that hyperexcitability induced by M-channel blockade affects motor coordination.

The findings for the ladder dexterity test were similar to those seen for the balance beam test after photothrombotic stroke (Fig. $6 E$ ). Again, we compared control mice (no drugs, $n=16$ ) to sham mice (operation only, $n=10$ ) and found no statistical difference in behavior $(p=0.98)$. However, the stroked mice displayed much slower progress on the balance beam, with significantly more mis-steps, compared with sham controls (RB only: $p<$ $0.001, n=8)$. Remarkably, mice with stroke plus RTG administration $(p=0.99, n=6)$, stroke plus NH29 administration $(p=$ $0.99, n=6)$, and stroke plus QO-58 administration ( $p=0.99$, $n=6$ ) again displayed no significant deficits in behavior, compared with the sham controls (Movie 2). Thus, the administration of all three M-channel openers at the time of the stroke completely prevented deficits in motor coordination resulting from photothrombotic strokes, and those mice showed a signif- 
A

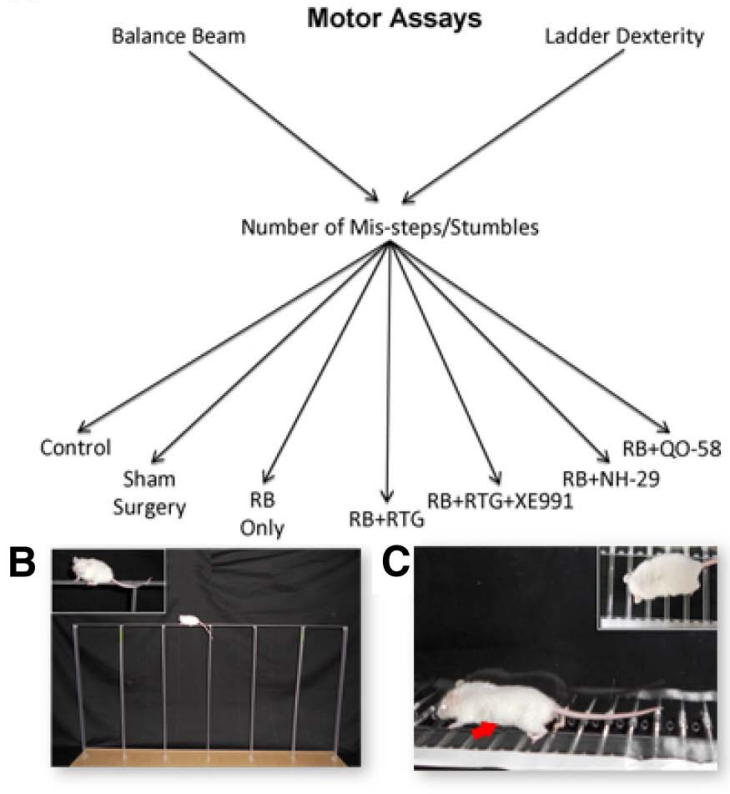

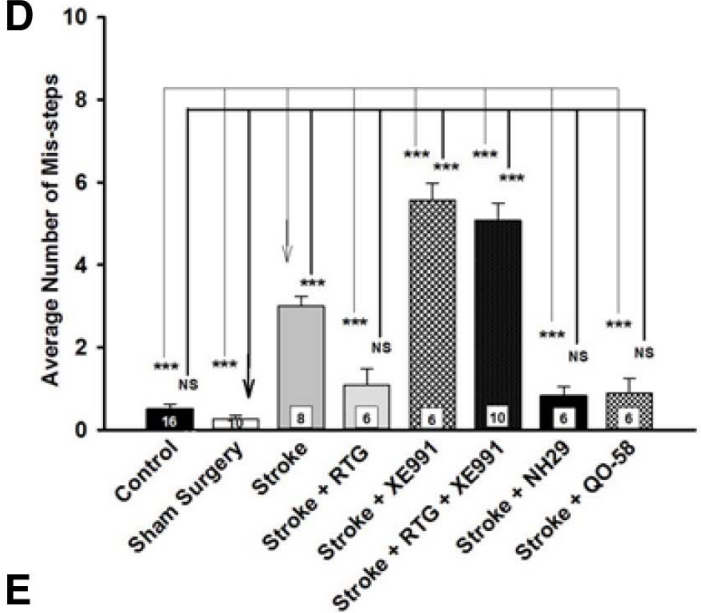

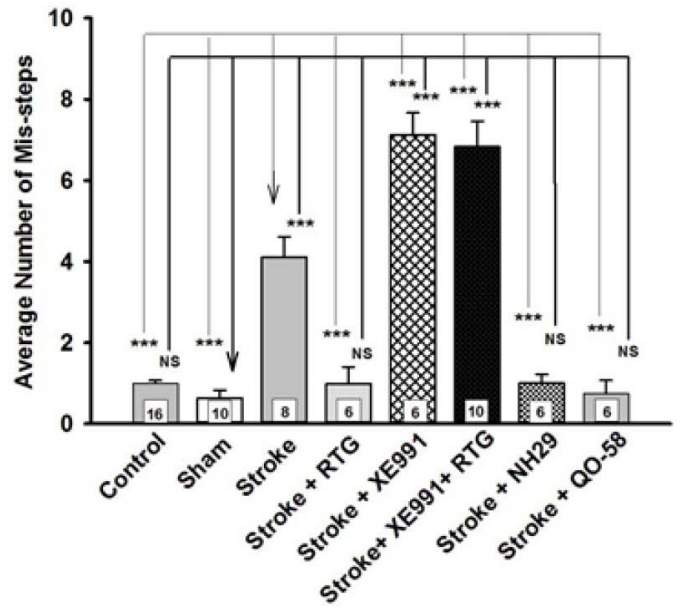

Figure 6. M-channel openers preserve poststroke motor function. $A$, Experimental paradigm and cohorts of mice to be tested. For each test, the cohorts were controls (no surgery); sham surgery; stroke only (no drug administration); stroke with RTG, NH29, Q0-58, and XE991 administration; or stroke with RTG plus XE991 administration. B, Image of a mouse on the balance beam, with a zoomed view in the inset. $C$, Image of a mouse on the ladder dexterity test, with azoomed view from above in the inset. An example of a mis-step is indicated by the red arrow. D, Summary of behavioral data for the balance beam test results of mice to which drugs were administered. E, Summary of behavioral data for the ladder dexterity test results of mice to which drugs were administered. The numbers of mice tested is given within each bar. The number of mis-steps is dramatically increased in the mice that were not given an M-channel opener or were coinjected with RTG plus XE991 in both behavioral models. ${ }^{* * *} p<0.001$ for sham and stroke comparisons.

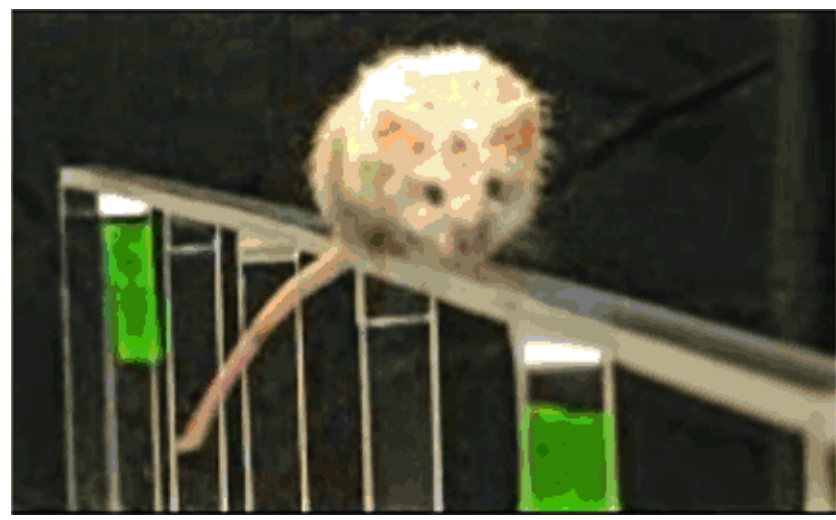

Movie 1. Enhancement of neuroprotection in stroked mice correlated with the preservation of motor functions to prestroke levels on the balance beam behavioral test. The multimedia file shows movement and foot slips for examples of mice from each cohort that traversed the balance beam.

icant decrease in the average number of mis-steps, compared with stroke-only mice (stroke plus RTG administration mice: $p<$ $0.001, n=6$; stroke plus NH29 administration mice: $p<0.001$, $n=6$; and stroke plus QO-58 administration mice: $p<0.001$, $n=6$ ). Conversely, the motor coordination displayed on the

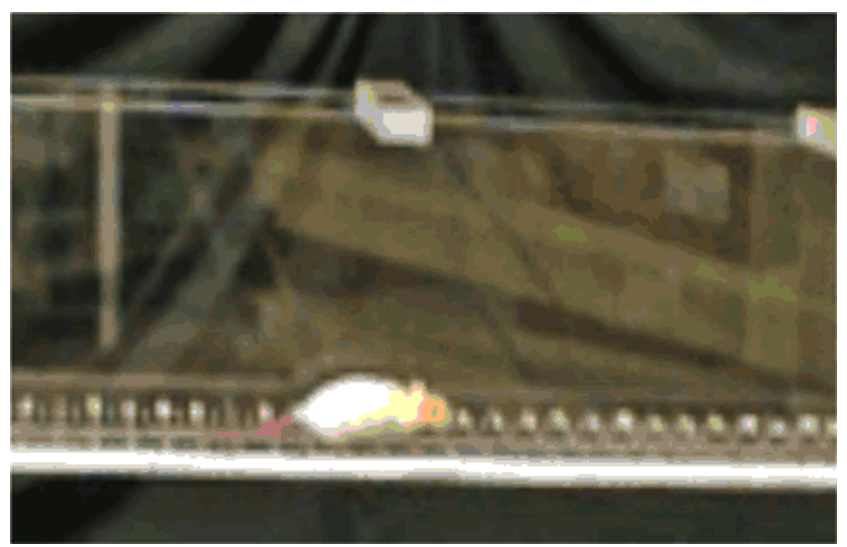

Movie 2. Enhancement of neuroprotection in stroked mice correlated with the preservation of motor functions to prestroke levels on the ladder dexterity test. The multimedia file shows movement and foot slips for examples of mice from each cohort that traversed the ladder in the ladder dexterity test.

ladder dexterity test of stroked mice given the M-channel blocker (either with or without RTG) was, again, much worse than that of the sham controls (stroke plus XE991 administration mice: $p<$ 0.001, $n=6$; stroke plus XE991 plus RTG administration mice: 
$p<0.001, n=10$; Movie 2). Again, such mice exhibited much greater numbers of mis-steps, stumbles, and long hesitations, which is consistent with fear-like responses. Thus, we obtained the stunning result that $\mathrm{M}$-channel openers wholly ablate deficits in motor coordination produced by the moderate strokes induced in the photothrombotic model, and that this efficacy is very likely due to specific actions of the drugs on M-channels.

\section{Discussion}

We show that the augmentation of M-channel activity after experimental stroke in mice results in both histologically and functionally neuroprotective outcomes. An obvious improvement was shown in M-channel opener-treated mice in the reduction of brain injury and functional impairment. The enhanced protection was less effective when the M-channel openers were used outside a clearly defined critical period of time (the "therapeutic window") and was prevented by M-channel blockade. The in vivo neuroprotective effects are likely caused by decreased excitotoxicity, which is known to heavily contribute to ischemic cell death. Our working model assumes that by decreasing the excitability of, or "silencing," neurons, we can rescue neurons in the penumbral region that are metabolically compromised but not yet damaged beyond repair. Furthermore, we established that enhanced neuroprotection correlates with in vivo administration of M-channel openers in models of both transient ischemic attacks and more catastrophic strokes. Finally, the enhancement of neuroprotection in stroked mice correlated with complete preservation of motor function. Since lesion size was consistent in the photothrombotic model, our behavioral test results support our histological findings.

Other pharmacological interventions specifically targeting neurons in the brain have failed to demonstrate efficacy in the clinic for decades. These include drugs targeting the AMPA and NMDA types of glutamate receptors; $\mathrm{Na}^{+}, \mathrm{K}^{+}$, and $\mathrm{Ca}^{2+}$ channels; and $\mathrm{GABA}_{\mathrm{A}}$ receptor agonists, with most of the failures due to lack of specificity, unacceptable side effects, or lack of efficacy in human brain (Donnan et al., 2008). Given the parallel molecular events occurring from seizures and vascular brain injuries, others have previously hypothesized that antiepileptic drugs to be efficacious against stroke-induced morbidity as well; however, all those drugs targeting excitatory ion channels or $\mathrm{GABA}_{\mathrm{A}}$ receptors have proven to be of marginal use (Calabresi et al., 2003). Interestingly, hyperexcitability underlies not only the pathophysiology of epileptic seizures, but also of chronic pain (Abogadie et al., 2002), and M-current openers are under investigation as an antinociception therapy as well (Miceli et al., 2008; Fleckenstein et al., 2013).

Despite having different structures, the compounds RTG, NH29, and QO-58 all had similar effects. The effects of RTG were blocked when RTG plus XE991 were coadministered, suggesting that the effects of RTG are mediated by specific actions on M-channels. Furthermore, doses of RTG at $10 \mathrm{mg} / \mathrm{kg}(\sim 0.05 \mu \mathrm{M})$ are within known effective ranges and under the maximally tolerated dose achieved in humans at $20 \mathrm{mg} / \mathrm{kg} / \mathrm{d}(\sim 0.1 \mu \mathrm{M}$; Gunthorpe et al., 2012). We note that the administration of XE991 alone at the time of the stroke resulted in an exacerbated lesion size and behavioral deficits, which is consistent with XE991 causing hyperexcitability (Zaczek et al., 1998) and with proper M-channel function being critical to neuronal survival. This is important, because $\mathrm{M}$ current is famously depressed by stimulation of Gq/11-coupled receptors, with its namesake muscarinic (M1) receptors being the most classic. Thus, we predict that cholinergic input to brain regions, such as the hippocampus (which is also the primary locus of temporal lobe seizures), that are known to have strong acetylcholine (ACh) release (Cobb and Davies, 2005; Lawrence et al., 2006) will exacerbate strokeinduced damage via closure of M-channels. Moreover, such cholinergic tone also stimulates excitatory ionotropic nicotinic ACh receptors, adding to excitotoxicity. It will be interesting to know whether cholinergic antagonists can have neuroprotective efficacy via these mechanisms.

It is widely accepted that a disruption of GABAergic synaptic transmission plays a pivotal role in neuronal hyperexcitability and, specifically, that a decrease of inhibitory responses contributes to the generation of ischemic insults (Pentón-Rol et al., 2011). Additionally, other studies (Zhou et al., 2008) have suggested that neuroprotection can occur from increased activity of GABA receptors that inhibits NMDA receptor-mediated nitric oxide (NO) production by neuronal NO synthase during ischemia. Furthermore, NO was shown to inhibit M-current in small-diameter trigeminal ganglion neurons, ultimately increasing excitability (Ooi et al., 2013). In the last few years, the role of excitatory amino acids in ischemic brain injury has become well established (McCulloch and Iversen, 1991). Glutamate is the most common excitatory neurotransmitter in the CNS and has been shown to be released excessively during ischemia (Guyot et al., 2001). Cerebral ischemia correlates with a rapid increase in extracellular glutamate, regardless of the primary cause of the ischemic insult, initiating a sequence of neurochemical events resulting in neuronal death.

The idea that the augmentation of $\mathrm{K}^{+}$channels in the brain could be neuroprotective during strokes has precedent. The compound BMS-204352 targeted $\mathrm{Ca}^{2+}$-sensitive maxi-K and KCNQ channels with the rationale of preventing pathological hyperexcitability of ischemic neurons, causing high levels of intracellular $\mathrm{Ca}^{2+}$, but that strategy was ultimately unsuccessful (Gribkoff et al., 2001). However, that research provided the valuable insight that drugs causing excessive activation of $\mathrm{K}^{+}$channels may have deleterious effects as well significant differences in effects at various dosing levels. Other $\mathrm{K}^{+}$channels tested in mice using this strategy have included the "two-pore, leak" (TASK, TRAAK) and $\mathrm{K}_{\mathrm{ATP}}$-gated (Kir6; Sun and Feng, 2013) types. For the two-pore types, inhibition or gene deletion of TASK1 channels, which are also enhanced by reactive oxygen species, increased the severity of MCAo strokes (Meuth et al., 2009), whereas gene deletion of TRAAK decreased the severity (Laigle et al., 2012). A neuroprotective role for Kir6 channels that are opened by depletion of ATP is logical; however, results suggesting that blockade of these channels by glibenclamide (Simard et al., 2009) actually improves poststroke outcomes in rats and the severe cross talk with those channels in the heart cast doubt on the utility of this target. A thorough study from the Clapham laboratory (Wu et al., 2012) highlighted voltage-gated proton channels (Hv1) as contributing to stroke-induced brain injury via participation in NADPH oxidase-mediated ROS production, and novel Hv1 therapeutics would indeed be interesting to test. Importantly, in none of these studies were results from modest stroke models, corresponding with the ischemic events commonly experienced in people, evaluated, as we do here. KCNQ1, KCNQ4, and KCNQ5 are expressed in vascular smooth muscle, and have been shown to be potent potential targets against vasoconstriction (Mackie et al., 2008), including cerebral vasospasm (Mani et al., 2013). Finally, the same photothrombotic stroke model as used in this study was used to implicate astrocyte metabolism in providing protection against brain injury (Zheng et al., 2010, 2013), and combinatorial 
therapy targeting neurons and astrocytes simultaneously is predicted to be powerfully efficacious in both animals and people.

Early work used a baboon model to show that after the onset of focal ischemia, measurements of electrical activity uncovered electrically silent regions, such as the penumbra, that were dysfunctional, but metabolically were not yet dead (Astrup et al., 1977). Thus, the challenge becomes to either restore adequate blood flow quickly after vessel occlusion or to protect viable tissue from mechanisms that lead to cell and brain tissue death. Importantly, although neurological dysfunction occurs immediately seconds to minutes after ischemic insult, the progression of ischemic injury and cell death continues in stages from minutes to days. Within the ischemic penumbra, multiple mechanisms have been identified over the past few decades that lead to irreversibly damaged brain tissue. Early restoration of blood flow by breakdown of the clot is known to decrease ischemic injury and this is done through the only Food and Drug Administrationapproved treatment, tissue plasminogen activator (tPA). However, tPA is only used in $<10 \%$ of patients and not at all after $\sim 4$ $\mathrm{h}$, since it has been shown to increase the risk of hemorrhage into the ischemic tissue. Furthermore, tPA may have other risks such as injury to the blood-brain barrier, activation of matrix metalloproteinases (Wang et al., 2003), and increased excitotoxicity in some experimental models (Nicole et al., 2001). Thus, combination therapies that ameliorate these effects may extend the therapeutic window of tPA while also mitigating the untoward effects. In the case of limited blood supply, ischemic cell death cannot be equated with limited ATP availability only, but rather tissue death develops as a result of numerous biochemical and cellular events that further stress the already compromised tissue (for a review, see Lo, 2008).

More than 20 years of research has focused on discovering and developing neuroprotective agents that might intervene in the ischemic cascade. Thus far, no protective agent has been shown to improve outcome in phase III clinical trials, but newer approaches continue to be investigated. Importantly, relatively few drugs have been shown to be neuroprotective (decrease infarction), and in fact many are known to cause acute brain edema and hemorrhagic transformation of the infarct. VEGF has been shown to aid in recovery (Sun et al., 2003), and purinergic agonists (Zheng et al., 2010) targeting astrocytes have shown rapid effects. Here, we show a viable option for protection of neuronal tissue without the additional insults to the already compromised brain and suggest that neuroprotection through specific openers of M-type potassium channels does not activate a global potassium channel response that worsens the chaotic poststroke environment. M-channel openers have the potential to reduce brain injury after modest and severe cerebrovascular events, and to preserve poststroke motor function, making them strong candidates to be tested for treatment of stroke in the clinic.

\section{References}

Abogadie FC, Bron R, Marsh SJ, Drew LJ, Haley JE, Buckley NJ, Brown DA, Delmas P (2002) Adenovirus-mediated G $\alpha$ q-protein antisense transfer in neurons replicates $\mathrm{G} \alpha \mathrm{q}$ gene knockout strategies. Neuropharmacology 42:950-957. CrossRef Medline

Astrup J, Symon L, Branston NM, Lassen NA (1977) Cortical evoked potential and extracellular $\mathrm{K}+$ and $\mathrm{H}+$ at critical levels of brain ischemia. Stroke 8:51-57. CrossRef Medline

Bederson JB, Pitts LH, Germano SM, Nishimura MC, Davis RL, Bartkowski HM (1986) Evaluation of 2,3,5-triphenyltetrazolium chloride as a stain for detection and quantification of experimental cerebral infarction in rats. Stroke 17:1304-1308. CrossRef Medline

Biervert C, Schroeder BC, Kubisch C, Berkovic SF, Propping P, Jentsch TJ,
Steinlein OK (1998) A potassium channel mutation in neonatal human epilepsy. Science 279:403-406. CrossRef Medline

Boscia F, Annunziato L, Taglialatela M (2006) Retigabine and flupirtine exert neuroprotective actions in organotypic hippocampal cultures. Neuropharmacology 51:283-294. CrossRef Medline

Braun JS, Jander S, Schroeter M, Witte OW, Stoll G (1996) Spatiotemporal relationship of apoptotic cell death to lymphomonocytic infiltration in photochemically induced focal ischemia of the rat cerebral cortex. Acta Neuropathol 92:255-263. CrossRef Medline

Brima T, Mikulecká A, Otáhal J (2013) Impacts of perinatal induced photothrombotic stroke on sensorimotor performance in adult rats. Physiol Res 62:85-94. Medline

Calabresi P, Cupini LM, Centonze D, Pisani F, Bernardi G (2003) Antiepileptic drugs as a possible neuroprotective strategy in brain ischemia. Ann Neurol 53:693-702. CrossRef Medline

Cheng YD, Al-Khoury L, Zivin JA (2004) Neuroprotection for ischemic stroke: two decades of success and failure. NeuroRx 1:36-45. CrossRef Medline

Cobb SR, Davies CH (2005) Cholinergic modulation of hippocampal cells and circuits. J Physiol 562:81-88. CrossRef Medline

Delmas P, Brown DA (2005) Pathways modulating neural KCNQ/M (Kv7) potassium channels. Nat Rev Neurosci 6:850-862. CrossRef Medline

Donnan GA, Fisher M, Macleod M, Davis SM (2008) Stroke. Lancet 371: 1612-1623. CrossRef Medline

Fleckenstein J, Sittl R, Averbeck B, Lang PM, Irnich D, Carr RW (2013) Activation of axonal Kv7 channels in human peripheral nerve by flupirtine but not placebo- therapeutic potential for peripheral neuropathies: results of a randomised controlled trial. J Transl Med 11:34. CrossRef Medline

Gamper N, Shapiro MS (2006) Exogenous expression of proteins in neurons using the biolistic particle delivery system. Methods Mol Biol 337: 27-38. CrossRef Medline

Gribkoff VK, Starrett JE Jr, Dworetzky SI, Hewawasam P, Boissard CG, Cook DA, Frantz SW, Heman K, Hibbard JR, Huston K, Johnson G, Krishnan BS, Kinney GG, Lombardo LA, Meanwell NA, Molinoff PB, Myers RA, Moon SL, Ortiz A, Pajor L, et al. (2001) Targeting acute ischemic stroke with a calcium-sensitive opener of maxi-K potassium channels. Nat Med 7:471-477. CrossRef Medline

Gunthorpe MJ, Large CH, Sankar R (2012) The mechanism of action of retigabine (ezogabine), a first-in-class $\mathrm{K}+$ channel opener for the treatment of epilepsy. Epilepsia 53:412-424. CrossRef Medline

Guyot LL, Diaz FG, O’Regan MH, McLeod S, Park H, Phillis JW (2001) Real-time measurement of glutamate release from the ischemic penumbra of the rat cerebral cortex using a focal middle cerebral artery occlusion model. Neurosci Lett 299:37-40. CrossRef Medline

Laigle C, Confort-Gouny S, Le Fur Y, Cozzone PJ, Viola A (2012) Deletion of TRAAK potassium channel affects brain metabolism and protects against ischemia. PLoS One 7:e53266. CrossRef Medline

Lawrence JJ, Saraga F, Churchill JF, Statland JM, Travis KE, Skinner FK, McBain CJ (2006) Somatodendritic Kv7/KCNQ/M channels control interspike interval in hippocampal interneurons. J Neurosci 26:1232512338. CrossRef Medline

Lo EH (2008) Experimental models, neurovascular mechanisms and translational issues in stroke research. Br J Pharmacol 153 [Suppl 1]:S396S405. CrossRef

Longa EZ, Weinstein PR, Carlson S, Cummins R (1989) Reversible middle cerebral artery occlusion without craniectomy in rats. Stroke 20:84-91. CrossRef Medline

Mackie AR, Brueggemann LI, Henderson KK, Shiels AJ, Cribbs LL, Scrogin KE, Byron KL (2008) Vascular KCNQ potassium channels as novel targets for the control of mesenteric artery constriction by vasopressin, based on studies in single cells, pressurized arteries, and in vivo measurements of mesenteric vascular resistance. J Pharmacol Exp Ther 325:475-483. CrossRef Medline

Main MJ, Cryan JE, Dupere JR, Cox B, Clare JJ, Burbidge SA (2000) Modulation of KCNQ2/3 potassium channels by the novel anticonvulsant retigabine. Mol Pharmacol 58:253-262. CrossRef Medline

Mani BK, O’Dowd J, Kumar L, Brueggemann LI, Ross M, Byron KL (2013) Vascular KCNQ (Kv7) potassium channels as common signaling intermediates and therapeutic targets in cerebral vasospasm. J Cardiovasc Pharmacol 61:51-62. CrossRef Medline

McCulloch J, Iversen LL (1991) Autoradiographic assessment of the effects 
of N-methyl-D-aspartate (NMDA) receptor antagonists in vivo. Neurochem Res 16:951-963. CrossRef Medline

Metz GA, Whishaw IQ (2002) Cortical and subcortical lesions impair skilled walking in the ladder rung walking test: a new task to evaluate foreand hindlimb stepping, placing, and co-ordination. J Neurosci Methods 115:169-179. CrossRef Medline

Meuth SG, Kleinschnitz C, Broicher T, Austinat M, Braeuninger S, Bittner S, Fischer S, Bayliss DA, Budde T, Stoll G, Wiendl H (2009) The neuroprotective impact of the leak potassium channel TASK1 on stroke development in mice. Neurobiol Dis 33:1-11. CrossRef Medline

Miceli F, Soldovieri MV, Martire M, Taglialatela M (2008) Molecular pharmacology and therapeutic potential of neuronal Kv7-modulating drugs. Curr Opin Pharmacol 8:65-74. CrossRef Medline

Nicole O, Docagne F, Ali C, Margaill I, Carmeliet P, MacKenzie ET, Vivien D, Buisson A (2001) The proteolytic activity of tissue-plasminogen activator enhances NMDA receptor-mediated signaling. Nat Med 7:59-64. CrossRef Medline

Ooi L, Gigout S, Pettinger L, Gamper N (2013) Triple cysteine module within $\mathrm{M}$-type $\mathrm{K}^{+}$channels mediates reciprocal channel modulation by nitric oxide and reactive oxygen species. J Neurosci 33:6041-6046. CrossRef Medline

Pamukcu B, Lip GY, Snezhitskiy V, Shantsila E (2011) The CD40-CD40L system in cardiovascular disease. Ann Med 43:331-340. CrossRef Medline

Pentón-Rol G, Marín-Prida J, Pardo-Andreu G, Martínez-Sánchez G, AcostaMedina EF, Valdivia-Acosta A, Lagumersindez-Denis N, Rodríguez-Jiménez E, Llópiz-Arzuaga A, López-Saura PA, Guillén-Nieto G, Pentón-Arias E (2011) C-Phycocyanin is neuroprotective against global cerebral ischemia/reperfusion injury in gerbils. Brain Res Bull 86:42-52. CrossRef Medline

Peters HC, Hu H, Pongs O, Storm JF, Isbrandt D (2005) Conditional transgenic suppression of $\mathrm{M}$ channels in mouse brain reveals functions in neuronal excitability, resonance and behavior. Nat Neurosci 8:51-60. CrossRef Medline

Rundfeldt C, Netzer R (2000) Investigations into the mechanism of action of the new anticonvulsant retigabine. Interaction with GABAergic and glutamatergic neurotransmission and with voltage gated ion channels. Arzneimittelforschung 50:1063-1070. CrossRef Medline

Schönbeck U, Mach F, Bonnefoy JY, Loppnow H, Flad HD, Libby P (1997) Ligation of CD40 activates interleukin lbeta-converting enzyme (caspase-1) activity in vascular smooth muscle and endothelial cells and promotes elaboration of active interleukin 1beta. J Biol Chem 272:1956919574. CrossRef Medline

Sidney S, Rosamond WD, Howard VJ, Luepker RV (2013) The "heart disease and stroke statistics-2013 update" and the need for a national cardiovascular surveillance system. Circulation 127:21-23. CrossRef Medline

Simard JM, Yurovsky V, Tsymbalyuk N, Melnichenko L, Ivanova S, Gerzanich V (2009) Protective effect of delayed treatment with low-dose glibenclamide in three models of ischemic stroke. Stroke 40:604-609. CrossRef Medline

Singh NA, Charlier C, Stauffer D, DuPont BR, Leach RJ, Melis R, Ronen GM, Bjerre I, Quattlebaum T, Murphy JV, McHarg ML, Gagnon D, Rosales TO, Peiffer A, Anderson VE, Leppert M (1998) A novel potassium channel gene, KCNQ2, is mutated in an inherited epilepsy of newborns. Nat Genet 18:25-29. CrossRef Medline

Singh NA, Otto JF, Dahle EJ, Pappas C, Leslie JD, Vilaythong A, Noebels JL, White HS, Wilcox KS, Leppert MF (2008) Mouse models of human KCNQ2 and KCNQ3 mutations for benign familial neonatal convulsions show seizures and neuronal plasticity without synaptic reorganization. J Physiol 586:3405-3423. CrossRef Medline

Stanley JL, Lincoln RJ, Brown TA, McDonald LM, Dawson GR, Reynolds DS (2005) The mouse beam walking assay offers improved sensitivity over the mouse rotarod in determining motor coordination deficits induced by benzodiazepines. J Psychopharmacol 19:221-227. CrossRef Medline

Sugawara T, Fujimura M, Noshita N, Kim GW, Saito A, Hayashi T, Narasimhan P, Maier CM, Chan PH (2004) Neuronal death/survival signaling pathways in cerebral ischemia. NeuroRx 1:17-25. CrossRef Medline

Sun HS, Feng ZP (2013) Neuroprotective role of ATP-sensitive potassium channels in cerebral ischemia. Acta Pharmacol Sin 34:24-32. CrossRef Medline

Sun Y, Jin K, Xie L, Childs J, Mao XO, Logvinova A, Greenberg DA (2003) VEGF-induced neuroprotection, neurogenesis, and angiogenesis after focal cerebral ischemia. J Clin Invest 111:1843-1851. CrossRef Medline

Wang HS, McKinnon D (1995) Potassium currents in rat prevertebral and paravertebral sympathetic neurones: control of firing properties. J Physiol 485:319-335. CrossRef Medline

Wang X, Lee SR, Arai K, Lee SR, Tsuji K, Rebeck GW, Lo EH (2003) Lipoprotein receptor-mediated induction of matrix metalloproteinase by tissue plasminogen activator. Nat Med 9:1313-1317. CrossRef Medline

Watson BD, Dietrich WD, Busto R, Wachtel MS, Ginsberg MD (1985) Induction of reproducible brain infarction by photochemically initiated thrombosis. Ann Neurol 17:497-504. CrossRef Medline

Wickenden AD, Yu W, Zou A, Jegla T, Wagoner PK (2000) Retigabine, a novel anti-convulsant, enhances activation of KCNQ2/Q3 potassium channels. Mol Pharmacol 58:591-600. CrossRef Medline

Wu LJ, Wu G, Akhavan Sharif MR, Baker A, Jia Y, Fahey FH, Luo HR, Feener EP, Clapham DE (2012) The voltage-gated proton channel Hv1 enhances brain damage from ischemic stroke. Nat Neurosci 15:565-573. CrossRef Medline

Yamato M, Egashira T, Utsumi H (2003) Application of in vivo ESR spectroscopy to measurement of cerebrovascular ROS generation in stroke. Free Radic Biol Med 35:1619-1631. CrossRef Medline

Zaczek R, Chorvat RJ, Saye JA, Pierdomenico ME, Maciag CM, Logue AR, Fisher BN, Rominger DH, Earl RA (1998) Two new potent neurotransmitter release enhancers, 10,10-bis(4- pyridinylmethyl)-9(10H)-anthracenone and 10,10-bis(2fluoro-4- pyridinylmethyl)-9(10H)-anthracenone: comparison to linopirdine. J Pharmacol Exp Ther 285:724-730. Medline

Zhao J, Kobori N, Aronowski J, Dash PK (2006) Sulforaphane reduces infarct volume following focal cerebral ischemia in rodents. Neurosci Lett 393:108-112. CrossRef Medline

Zheng W, Watts LT, Holstein DM, Prajapati SI, Keller C, Grass EH, Walter CA, Lechleiter JD (2010) Purinergic receptor stimulation reduces cytotoxic edema and brain infarcts in mouse induced by photothrombosis by energizing glial mitochondria. PLoS One 5:e14401. CrossRef Medline

Zheng W, Talley Watts L, Holstein DM, Wewer J, Lechleiter JD (2013) P2Y1R-initiated, IP3R-dependent stimulation of astrocyte mitochondrial metabolism reduces and partially reverses ischemic neuronal damage in mouse. J Cereb Blood Flow Metab 33:600-611. CrossRef Medline

Zhou C, Li C, Yu HM, Zhang F, Han D, Zhang GY (2008) Neuroprotection of gamma-aminobutyric acid receptor agonists via enhancing neuronal nitric oxide synthase (Ser847) phosphorylation through increased neuronal nitric oxide synthase and PSD95 interaction and inhibited protein phosphatase activity in cerebral ischemia. J Neurosci Res 86:2973-2983. CrossRef Medline 